\title{
More than a third of GPs on commissioning groups have conflicts of interest, $B M J$ investigation shows
}

This recent $B M J$ investigation by Gareth Iacobucci ( $B M J$ 2013;346:f1569, doi:10.1136/bmj.f1569) stated that five general practitioners on the governing body of NHS Blackpool Clinical Commissioning Group (CCG) listed interests in Virgin Care. This statement was based on a list of registered interests provided by NHS Blackpool CCG via a Freedom of Information request. The $B M J$ would like to clarify that the interests registered in Assura Blackpool— the limited liability partnership jointly owned by Virgin Care and local practices-were held through the GPs' practices and not individually. Additionally, Virgin Care has since disclosed that the local practices in question have now resigned from Assura Blackpool.

Cite this as: BMJ 2013;346:f2043

๑ BMJ Publishing Group Ltd 2013 